\title{
Policy of Turkish Justice and Development Party (Adalet ve Kalkınma Partisi) in Internal Reform
}

\author{
Ahmed Y.M. Alahmed \\ Universiti Kebangsaan Malaysia \\ Email: ahmed17w17@yahoo.com \\ Wan Kamal Mujani \\ Universiti Kebangsaan Malaysia \\ Email: inamal@yahoo.com
}

Doi:10.5901/mjss.2015.v6n4s1p318

\section{Abstract}

The Turkish Justice and Development Party has repeatedly won the general elections, both the Parliamentary and the Municipal, from 2002 until 2014. Its latest big victory has been the one that was held in March 30, 2014, in which the Party maintained control over the main and important cities such as Ankara and Istanbul. There are a number of reasons for such a repeated victory, among the most important of which is the Party's internal policy that is represented by rescuing the critical economic situation the country was suffering from. Among the reasons are also allowing for a wide space of public freedom and enhancing the standards of democracy and human rights. A further reason for the Party's repeated victory is the gradual nullifying of the military institution which had ruled the country for a long period of time and led many military coups that deteriorated Turkey in all aspects of life. Moreover, the Party has neutralized the judicial institution and made a real effort to establish an independent judiciary system. In addition, the Party has paid a great attention to the health sector as well as the social, cultural and educational fields. In this latter regard, the government of the Justice and Development Party has witnessed the biggest budget for education in the history of the Republic. All those efforts have contributed to the increase of the public credit of the Justice and Development Party. Thus, the Party's internal policy has witnessed a big success in the process of the comprehensive reform.

Keywords: Turkish Justice and Development Party; politic; social; economy; reform;

\section{Introduction}

The most important fields that the government and state leaders encounter are those that concern both the internal and external affairs. The internal affairs file is concerned with everything related to individuals in public life such as political, economic, social or personal affairs. In many important historical phases, the external file has occupied the attention of state leaders and left a negative impact on the internal affairs of a country. Consequently, such situation negatively reflects on all citizens. The leaders of the Justice and Development Party have been aware of such facts since their first arrival to power. Twelve years ago, specifically in November 2002, the Party won the parliamentary elections in which it got 351 seats out of a total of 550 seats. As such, despite its recent establishment, the Party won a very big victory which enabled it to form a government alone with no need for any coalition that could impede its policies and programs (Khammash, 2010).

The Party has been able to balance between the political values and the political practice through the adoption of political tools and programs upon the internal situation. In this regard, the Turkish Prime Minister, Erdoğan, points out the importance of paying attention to the citizens' public needs. He realized well the importance of contacting with people when he was the Mayor of Istanbul (Habib, 2009). The Party has made much social, economic, political and military reform.

\section{Reform in Social Field}

The Justice and Development Party believes that all Turkish citizens are equal in rights regardless of gender, race or religion. It also considers the Republic of Turkey to be based on secularism, democracy, law, social and civilization 
processes, freedom of thought and justice of chance (Hassan, 2012). The fathers of the Justice and Development Party attempted to adopt policies that achieve balance between the external relations and the internal affairs. It thus has a new thought and philosophy that the fathers of the Party view in harmony with the Turkish political reality as well as with the Party's internal environment. The Party has presented itself in new ways so as to be close to all the Turkish people regardless of race, thought and political affiliation. That is to say that it does not give itself a certain form for certain people. Consequently, it does not define itself as an Islamic party, rather it keeps away from that which could identify it as having an Islamic agenda (Al-Harub, 2008).

Article 4 of the Party's rules of procedure includes a group of principles and basics that the Party believes in and defends, among the most important of which are that the Party believes in the Turkish nation as one nation, that man is its focus of attention, that freedom of religion and thought is for all people regardless of race, language or gender and that it rejects all forms of discrimination that are contrary to the basics of a democratic society. In its basic Charter, the Party emphasizes on the citizens' rights of life as they choose and guarantees their freedom of thought and expression as they like (Turkish Justice and Development Party, 2013).

The Party also presents itself as a strong defender of human rights and all forms of public freedom whether religious, intellectual or political. All through the Party's rule which extends to twelve years, the Party leaders have endeavored to establish rules of justice among all groups and classes of the Turkish society. One of such rules of justice is the social justice as well as that of distribution and equality of chance. Article 4 of the Party's basic Charter states that the Turkish state believes in the principles of the present human civilization such as human rights, public freedom and peoples' right in independence of any oppression. Therefore, the Party stresses on its adherence to the principles of democracy. It declares its acceptance of the democratic process results that come through voting. It also emphasizes on spreading out the meanings of democracy in the Turkish society so that democratically-based work becomes an asset of the politics of the Republic of Turkey. At a time that it adheres to the values, lofty example and deeply-rooted history of the Ottoman's Empire, the Party is very much concerned to keep pace with and benefit from the world developments in all walks of life. This means that the Party balances between the old and the new, the traditional and the modern. Therefore, the Party considers itself a conservative democratic party; combining between rationality and compromise; coupling the traditional and the modern (Habib, 2009).

To gain the Turkish support, the Justice and Development Party adopts an effective style in its internal policy which is using a media discourse that harmonizes with all people, exactly the same as its diplomatic style in its foreign policy that achieved a big success and left a conspicuous impact on many international and regional activities. As a result, the Party was described as a moderate party that does not clash with the West as it adopts capitalism with control over the state economy. It also avoids using religious slogans in its political discourses (Saleh, 2013).

The Party pays a special attention to the concept of the social state which is considered an approach to the welfare of man. It is also concerned with representative democracy that is based on pluralism, participation, competition and the existence of civil society institutions so as to achieve the meaning of a modern state. At the social level, the Party considers family a social institution that bridges the past and the future and is thus a basis of the Turkish society (Turkish Justice and Development Party, 2013).

Some of the most important reforms and achievements of the Party are represented in the health sector. The government followed the system of a family doctor in all cities in 2010. Between 2002 and 2010, 251 hospitals were established, in addition to 1028 health centers. The budget of the Health Ministry increased to 13.4 million Turkish Lira in 2010. The government also established 49 state universities where their number became 102 universities. 29 private universities were also established where their number became 52 universities. A number of reforms were made to the field of education where the education budget has become the biggest one ever during this short rule of the Justice and Development Party, even bigger than that of the Defense (Al-Saeed, 2013).

At the social level, some of the Party's achievement is represented by the conformity and harmony that exist among all the types of people and races in the Turkish society. The cultural and political developments that the Ottoman State underwent toward the end of the 19th century and the beginning of the 20th century have participated in shaping the modern Turkish identity. During that time, a number of identity-based demands and conflicts evolved in Turkey. In response, the State was very conservative where two factors, namely nationalism and secularism, were adopted to encounter the political and cultural movements that sought change (Thalji, 2009).

Samuel Huntington considers Turkey the country that suffered the most from the identity crisis. He describes it as a torn country whose leaders try to make it a part of the West despite the non-Western nature of its culture, history and traditions. Oglu, the Minister of the Foreign Affairs, realizes this trouble when he points out the dangerous nature of the identity crisis that the Turkish society experiences and its effect on the Turkish social fabric (Thalji, 2009). Therefore, the government of the Justice and Development Party has endeavored to overcome this problem and achieve social 
conformity among the Turkish people.

\section{Reform in Economic Field}

In the policy of the Justice and Development Party, the economic field got much concern. In this regard, Turkey has drawn the external economic plan based on its new comprehensive strategy. The plan proceeded as expected. The endeavor toward joining the European Union has been resumed. Also, the Party heads toward establishing new partnerships with the Arab World. These partnerships would participate in widening the economies in the region; thus, establishing a new economic field that opens up toward the Central Asia, especially after the collapse of the Soviet Union and gives the Turkish politics an oriental taste (Al-Himsh, 2012).

The difficult Turkish economic situation had posed a very big challenge to the Party when it came to power as there were many problems and crises. In 2002, When the Party got to power, Turkey was living an economic crisis, and the State was passing through a very big financial and commercial trouble. Economic growth was just $3 \%$ until 2002 . The average personal income did not exceed $\$ 3000$, and the national production was not more than 300 billion dollars (Nassar, 2011). This crisis revealed itself clearly in the financial disorder that struck banks, increase of finance deficit, rise of the external debt, decrease of foreign exchange reserves and constant rise of interest rate (Ozturk, 2009).

Such was the crisis ahead of the Justice and Development Party which had been new to power. The economic crisis had reached a stage in which the Turkish lira lost $70 \%$ of its value. To encounter such critical situation, the Turkish government represented by the Party put an economic plan to rescue the State, in which the government reactivated all the economic relations inside the country and benefited from all possible means available. The new economic vision was based on correcting the productivity efficiency so as to achieve the expected objectives of the plan (Gul, 2013).

The new economic plan and programs have been implemented in an integrative way to achieve success in record time. The Turkish economy has experienced a radical transformation within the period from 2002 to 2008 where the national production increased from 300 billion dollars to 750 billion dollars; the personal income rose to reach $\$ 10000$; the inflation rates constantly decreased and investments gradually increased. Turkey then ranked number 16 economically and number 6 at the level of Europe (Ozturk, 2009). Further, the Turkish economic growth doubled compared to it self in 2002, where it reached 1.1 trillion dollars. Thus, Turkey forms the biggest economy in the Middle East. Due to such advanced and wise economic policies, the Turkish banks have become very strong to the extent that they did not get affected by the international economic crisis of 2008. Thus, the Turkish government has been able to overcome the main problems that it faced and achieved a big economic development in record time, the positive effects of which reflected on the Turkish life in general.

Such development was based on an economic strategy conducted by the Justice and Development Party to achieve the economic integrity in the region. Turkey is a member in the Organization for European Economic Cooperation. It has also held a customs valuation agreement with the European countries for 12 years. It is also a member in the Organization of the Islamic Conference and is one of the first ten members in the capital of the Saudi Fund for Development. It also has agreements for strategic cooperation with the Cooperation Council for the Arab States of the Gulf. It has signed an agreement for economic integration with the Arab states. The New economic strategy was of two directions: the first is to establish a new economic field in the Central Asia and the second is to establish new partnerships with the Arab states and developing the trade cooperation with them (Al-Himsh, 2012).

The reason for that is the existence of the many trade incentives for Turkey in the Arabic region. Among such incentives is that the Arabic region represents a big market for the Turkish goods. The closeness of the Turkish geographical location to the Arabic region also makes it easy for the Turkish goods to transport. In addition, the Arab peoples like to purchase the Turkish products. A further incentive for Turkey in the Arabic region is the oil which exists in abundance (Hawa, 2012).

Turkey also made good relations with Iraq which has a wealth of oil. Between 2009 and 2010, Turkey tried to benefit from the contracts of developing the Iraqi oil wells. It signed three oil and gas contracts; and this was a reason to develop the relations between the two countries. Such contracts helped establishing a raw oil pipe which was a reason for the development of the economic relations between Turkey and Iraq. This step led to developing the trade exchange in big rates, in addition to the increase of goods, services and contracts from the Turkish side to Iraq. The trade exchange reached billions of dollars; and the economic dependence of Turkey on Iraq increased.

Such policy in developing the economy has resulted in an increase of the economic capacities in Turkey. Turkey has thus excelled all its neighbors in the economic achievement where it owns a wide industrial base and possesses huge human wealth. Its agriculture progresses conspicuously. Turkey has become one of the strongest growing economies. Based on the report of human development, in 2003, Turkey ranked number 96 out of 175 countries, and in 
2010, it was number 83 out of 169 countries. Further, its national production and personal income increased. The Turkish economy has achieved an annual growing rate that reaches to $5.3 \%$. The inflation waves and the deterioration of the Turkish lira stopped (Salim, 2012).

At the regional level, this policy has also led to building a strong economy with which Turkey has become a third growing state in the world and number 17 in the world economy. The Turkish government is considered one of the most successful ones in managing the world economic crises; for despite the economic crisis that the Party encountered at the beginning of its administration of the country, the Turkish economy survived the crisis and gotten stronger. All this was due to the policy that the Justice and Development Party follows which led to the developing the economic plans and maintaining the Turkish economy strong in the face of the global crisis. Such policy succeeded in achieving the Party's program of economic and political reform in a good way (Bobosh, 2011).

There were radical changes in the Turkish economy between 2000 and 2005 where the inflation rate decreased from $70 \%$ to $7.6 \%$ and the average of personal income out of the national production increased from $\$ 2500$ to $\$ 5000 \mathrm{a}$ month. Concerning the external trade, the Turkish exports rose as follows: from 36, 47, 63 to 73.4 billion dollars in 2002, 2003, 2004 and 2005 respectively. Also, compared to 2004, the size of trade exchange between Turkey and the European Union increased by $8 \%$ in 2005. In this, Turkey excelled other countries such as South Korea and Canada which are considered among the main competitors in the Union. Turkey has become close to Japan which is the biggest exporter to the European Union (Saber, 2012).

With regard to the success of the economic strategy initiated by the Justice and Development Party, the Turkish economic expert, Ahmad Owaisal, is of the opinion that there are many factors to its success. One of such factors is that Turkey has been able to achieve development without relying to oil income as is the case with the oil countries. The Turkish economy did not rely on foreign aids, rather it depended on itself. Other factors are the implementation of democracy, belief in freedom, activation of the role of the civil society and the active leadership that nurtures the economic growth and constant development. In addition to those factors is the presentation of new programs that lead to freeing the economy from external and internal chains.

What also led to the success of the Turkish economy are the change from the import policy to the national production and the cancellation of all forms of support and lowering the state portion in the economic activity. This has also led to the decrease of the external debt and doubling of external trade size. Thus, Turkey has become an active and global competitor. Owaisal states that there are also other reasons that helped the Turkish economy to be successful, among which is the political stability. Since 2005 , there has just been one government that achieved the political stability which enhanced the economic development as well as overcame the judicial and political obstacles. The latter steps helped restrict the role of the army in the political life. Fuat Erdal, an economic expert at Istanbul University, views the reason behind the success of the Turkish experience to be the development of the logistic, transport, information and telecommunication infrastructures as well as aiming at new markets to increase the external trade. Further, among the reasons of that success are the incentive programs of export, providing the required finance for developing marketing research projects, attracting more foreign investments and focusing on small and medium projects (Al-Barbari, 2014).

Some studies described the Turkish strategy in economy as a miracle, for the Turkish Republic has been living a stage of big transformation under the rule of the Justice and Development Party since 2002. The demographic factor of Turkey as well as its political stability stress that the Turkish miracle could at least continue until 2020. This state would present Ankara as a regional power. The Turkish economy is also described as the biggest economy in the Middle East. Turkey could also compete with Spain and Italy and then become the biggest economy in the Mediterranean region (Cagaptay, 2011).

This experience is described as a miracle due to the big development that occurred within that short period of time, for when the Justice and Development Party reached power in 2002, the economic situation was at its worse. Turkey passed a critical and dangerous economic crisis in 2001, something that resulted in the decrease of growth rates and in sharp increase of both the inflation rates and the finance deficit in the state budget. The interest rate also got raised. The state economic sectors could not endure all that, something that deteriorated the economic situations. However, the new government led by the Justice and Development Party has resolved many problems through its wise economic plan (Ozturk, 2009). The Party's economy plan led to the increase of growth rates as follows: increase in investment size for about four times and a half as well as doubling the production; rise in employing the capitals from $75 \%$ to $80 \%$; increase in the investment rates for about $300 \%$ in the private sector and $100 \%$ in the state sector and increase in consumption for about $39 \%$ in the private sector and $22 \%$ in the state sector. All such indicators reveal the solution of the problem that Turkey lived in 2001. 


\section{Reform in Political Field and Impeding Army Influence}

Political reform was one of the achievements conducted by the Justice and Development Party. It is one of the reasons behind the Party's public credit in Turkey. The Party has put its focus on the civil society where all citizens are equal in rights and duties. It possessed a comprehensive vision that springs from the national priority (Bobosh, 2011). Therefore, the Party's leadership avoids the political discourse that is ideological, racial or religious, for such discourse would certainly leads to cancelling the other. The Party views the Turkish people as equal regardless of gender, race, religion, thought or political affiliation. It also views the Turkish Republic to be based on secularism, democracy, law, social and civilization processes, freedom of thought and justice of chance (Hassan, 2012).

Therefore, the government of the Justice and Development Party seeks to achieve and guarantee freedom to its citizens without any negative consequences threatening the Turkish national security internally or externally. Such strategies participated in making a number of political, economic, cultural and social reforms concerning the status of the minority groups such as the Kurds and Alawites. This step has added to the popularity of the Justice and Development Party among such minorities. Such policy springs from the Turkey's attempt to establish a strong link between freedom and security. The government has thus headed toward achieving freedom and democracy simultaneously. It has a view that achieving freedom must not be at the expense of security; both should to together (Abdulqader, 2012).

The government headed toward establishing the bases of the civil society and deconstructing all indicators of the army rule that contradicts with democracy and collapses politics. Here, the Justice and Development Party encountered a big challenge in spreading democracy and ending the army's spread in the state institutions. The encounter of the Party with the army was the biggest challenge, for the previous encounters with the army ended all the Islamic parties by banning them under the pretext of protecting the secular state from the Islamists who were then sent to jails or exile. The military coups were repeatedly present in Turkey due to the influence and spread of the military institution in the state apparatuses.

Historically speaking, the first military coup was in 1908 in which a general constitution was declared, the Sultan Abdulhamid the Second was removed from the throne and an officer from the Committee of Union and Progress was brought to power. Since the early sixties of the last century, Turkey has witnessed four military coups, the first of which was on $27 / 5 / 1960$. Then the second military coup was on 2/3/1971. The third military coup, and the biggest in the history of the Turkish Republic, was in 1980. Due to this third coup, the 1982 constitution was declared. This had been the constitution that helped root the army in all fields of life. The fourth military coup occurred on 28/2/1997 (Abduljalil, 2009). The army institution has indirectly but strongly stood against the Justice and Development Party. Through media, the military institution attempted to grow fear from the Party because of the Islamic background of its leaders. It also highlighted what it was called as the hidden agendas of the Party that could not be seen and no one can prove. Further, the army officers joined the opposition parties which were 40 parties in Turkey. Despite the differences between those parties, they united against the Justice and Development Party.

Therefore, Haider Yildiz, one of the Party's officers in Istanbul, states that the Party has encountered a fierce and life-and-death battle, for it faced the most extreme secularists whether civilians, military officers, businessmen or media people (Huwaidi, 2010).

At that time, the military officers had had much authority granted to them by the 1982 constitution which resulted out of the biggest military coup ever in the history of the Turkish Republic. That institution enabled the military officers to interfere in all fields of life. In it, the Article 13 declares the ban of religiously-, fascist- and socialist-based parties. And the Article 35 states that the army has the right to defend the nation, the constitution and the secular Republic. This had been an entry to the army to interfere in all fields of life under the pretext of protecting the constitution. Further, the Article 96 states the ban of using the communist, absurdist, socialist, fascist, nationalist, racialist, linguistic and sectarian terminologies or any other words that could give similar meanings.

The just mentioned constitution has aroused much debate in Turkey as a constitution that restricts basic rights and freedoms among which are the freedom of speech, religious expression and gatherings (Hardy, 2009). The lawyer, the constitutional expert and the President of the Human Rights Association, Ozturk Turkdogan, describes that constitution as reflecting the official ideological vision which adopts disrespect of human rights and political and national pluralism. It is a constitution that neither recognizes the freedom of expression nor the freedom of religion. It obliges all people to be Turkish via national identity alone (Al-Sharqawi, 2006).

That has been the Turkish reality which was controlled by the military institution at all aspects of life and supported by constitutional texts that granted the army full and unlimited right of administration and interference. The military coups in Turkey were different from those that happen in the Third World as they were carried out under the cover of the constitution and the protection of the Republic, system and laws (Noor, 2009). 
In the face of such reality, the Justice and Development Party tried to coexist with the military institution at the beginning. Then it sought to limit the military officers' responsibilities and hegemony over the political life by means of expanding the political and civil freedoms in Turkey through constitutional amendments and laws.

In this regard, the Turkish Parliament voted for the sake of a group of amendments in 2003 that aimed at limiting the authorities of the National Security Council. Among such amendments was the possibility of appointing a civil personality for the position of the general secretary of the National Security Council. Also, the amendments state that the right of appointing such a personality was the responsibility of the Prime Minister, not the Chief of Staff. Further, the National Security Council should be held every two months, not every month; and its role should just be consultative. In 2004, the Turkish government has also carried out a group of constitutional amendments that aimed at further limitation of the military officers' roles. The new amendments banned the participation of the army representative in the meetings of the Supreme Council of Higher Education. They also grant the citizens the right of prosecuting cases before the constitutional court.

However, the constitutional amendment that the Parliament managed to carry out in September 2010 was the most important and daring amendment in restricting the military officers' role, for it included 26 items, among which are items that relate to the reorganization of the supreme judiciary authorities opposing the Justice and Development Party. Such an amendment has gained 58\% of the Turkish public support (Turkish Justice and Development Party, 2013). The constant attempts of amendments by the Turkish Parliament have been the best method to restrict the military officers' role. They helped Turkey move toward the democratic process away from the hegemony and influence of the military institution and Army officers. Therefore, the 1982 constitution has been amended 17 times beginning from 1987 until 2010. The constitution had included 194 Articles from which 100 Articles were amended (Al-Sharqawi, 2006).

With such constitutional amendments, the Justice and Development Party has managed to put an end to the military hegemony over the political life. Besides, the Turkish Judiciary has prosecuted an army officer that tried to topple the government from power in 2003. In 21/9/2012, the Turkish judiciary passed severe judgments upon 300 officers convicted of trying to topple the government in 2003. Most of those prosecuted were banned from working in the state sector, among whom were army leaders convicted of taking part in a conspiracy called Sledgehammer aiming at toppling the Justice and Development Party from power. This trial is one of the biggest issues related to conspiracy that occupied the Turkish judiciary since 2007 (Anadolu Agency, 2013).

Such Turkish amendments have raised the trust in talking about the end of military coups. The Turkish Prime Minister, Ordoghan, stresses that the time of military coups in Turkey is a history and that anyone attempting to interfere in democracy will be presented before courts and questioned (Al-Jazeera, 2013).

Managing the economic crisis and the problem with the military officers were the most prominent internal challenges that encountered the Justice and Development Party which achieved a big success in countering them. The Party achieved a big progress economically as the statistical indicators show that the economic leap is maintained. It also succeeded in disintegrating the iron fist of the military officers who ruled the country and led many coups against the previous governments. The son of the Prime Minister Ordoghan publicly states that there is no return to military coups and the country will only be ruled through voting.

Those have been the most prominent changes carried out by the Justice and Development Party with regard to the military institution. In this regard, one can say that the Party has succeeded in achieving big success in two directions; the first was at the level of politics and reality where a liaison was established between them, something that increased the Party's public support. The second was at the level of revealing the secular tyranny. Here, the Party managed to neutralize the military institution through constitution aided by a real public support (Khammash, 2010).

In this regard, the Party's most prominent achievements are represented by neutralizing the military institution and restricting the army's influence. This has given much space for freedom and helped establish the standards of democracy, respect of human rights and end the state of emergency in the south of Turkey (Al-Saeed, 2013).

\section{Concluding Remarks}

Upon receiving the administration of Turkey, the Justice and Development Party has shown much concern to the internal situation. The Turkish citizen has felt the impact of change in reality. At the social level, the reforms were evident in dealing with all citizens as equal without discrimination. At the economic level, Turkey has witnessed genuine economic development in a short time during which it managed to pay back all its debts to the International Monterey Fund. At the political level, the democratic concept was established, and the military institution control over the country was deconstructed. Such reform and success achieved by the Party has increased its public credit in Turkey, something that has been one of the main reasons to the continuous success in elections since 2002. 


\section{References}

Abduljalil, T. (2009). Army and the political life: deconstructing the iron fist. In Muhammad Abdulatti (Ed.), Turkey between Internal Challenges and External Wagers. 65-85. Beirut: Arab Scientific Publishers; Doha: Al-Jazeera Center for Studies.

Abdulqader, Muhammad. 2012. Turkish Foreign Policy under the Justice and Development Party. Doha: Arab Center for Research \& Policy Studies.

Al-Barbari, A. (2014). Orientation of Egyptian-Turkish Relations after January Revolution. Journal of Al-Siyassa al-Dawliya. [Online] Available: http://www.siyassa.org.eg/NewsContent/6/51/306 (April, 26, 2014).

Al-Harub, K. (2008). Turkey: Islamic and secular. Weghat Nazar, October: 117

Al-Himsh, M. (2012). An Arab Perspective Concerning the Turkish-Arab Economic Relations. Doha: Arab Center for Research \& Policy Studies.

Al-Jazeera.net. (2013). http://Aljazeera.net/portal . (Disember 15, 2013).

Al-Saeed, S. (2013). The Turkish Foreign Policy under the Justice and Development Party and Its Consequences on the Turkish-Arab Relations. Algeria: Mohamed Khider University.

Al-Sharqawi, M. (2006). The Turks Empowered Ordoghan and Postponed the Constitution, [Online] Available: www.almoslim.net (June 14, 2006).

Anadolu Agency. (2013). [Online] Available: http://www.aa.com.tr/ar (Febuary 2, 2013).

Bobosh, M. (2011). New Directions in Turkish Foreign Policy. Journal of Middle Eastern Studies. 55, 37-70.

Cagaptay, S. (2011). Turkish Economic Miracle. Washington: The Washington Institute.

Gul, Muhammad Z. (2013). Turkish Renaissance Experience. Beirut: Namaa Center for Research and Studies.

Habib, K. (2009). The Turkish Role: From Bridge to Deep Inside. Journal of Middle Eastern Studies, 48, 121-136.

Hardy, L. (2009). The compelling case of Turkey's constitution. Alwasat News, Bahrain (January 4, 2009).

Hassan, S. (2012). The Turkish developmental role in the Palestinian Occupied Lands under the rule of the Justice and Development Party 2002-2010. M.A thesis, Al-Najah University, Nablus.

Hawa, H. (2012). Arab-Turkish Free Trade Zone. Doha: Arab Center for Research \& Policy Studies.

Huwaidi, F. (2010). The Democratic Coup in Turkey. Beirut: International Arab Center for Solidarity and Communication.

Khammash, Rana A. (2010). Turkish-Israeli Relations and Its Impact on the Arabic Region. Amman: Center of Middle Eastern Studies.

Nassar, F. (2011). The Turkish Justice and Development: Four Reasons behind the Victory, [Online] Available: http://voc.ed.psu.edu/ projects/publications/books/Fall2004/index.html (June 15, 2011).

Noor, T. M. (2009). Military coups: Turkish model. In The Military Influences on the Political Process in Sudan. Al-Khartoum: Epistemological Enlightenment Centre, [Online] Available: www.tanweer (June 30, 2009).

Ozturk, I. (2009). Turkish economic transformation between 2002 and 2008. In Muhammad Abdulatti (Ed.), Turkey Between Internal Challenges and External Wagers. 47-64. Beirut: Arab Scientific Publishers; Doha: Al-Jazeera Center for Studies.

Saber, F. (2012). Turkish Strategic Options and the Arab World. Doha: Arab Center for Research \& Policy Studies.

Saleh, Mohsen (2013). Turkey and Palestinian Cause. Beirut: al-Zaytouna Centre.

Salim, Muhammad al-Sayyed. (2012). New Turkish Roles in the Arab World: The Alternative and Strategic Model. Doha: Arab Center for Research \& Policy Studies.

Thalij, M. (2009). Identity crisis in Turkey: new ways of treatment. In: Muhammad Abdulatti (Ed.), Turkey Between Internal Challenges and External Wagers. 87-108. Beirut: Arab Scientific Publishers; Doha: al-Jazeera Center for Studies.

Turkish Justice and Development Party. (2013), [Online] Available: http://eng.akparti.org.tr/english/partyprogramme.html (November 15, 2013). 